\title{
THE INFINITE ROUNDS OF THE STUBBORN: Reparative Futures at a French Political Protest
}

\author{
ELI THORKELSON \\ Whittier College \\ (D) http: / / orcid.org/0000-0003-4409-3301
}

If futures are always plural, then we might reasonably expect that any given cultural formation of the future is in dialogue with other futures, or in conflict with them. ${ }^{1}$ Gustav Peebles $(2008$, 238), in an analysis of the nationalist politics of paper currency, has suggested that "the state, long recognized as a colonizer both of the past and of physical territory . . proves itself adept at colonizing the future, as well.” But we might well ask: is the state always successful in this grab? Or can futures be decolonized, as it were? If futures can get confiscated, misdirected, or disrupted, then how might they subsequently get reappropriated, repaired, or reconnected? What is the relationship between activist futures and state futures? It is this line of inquiry that I take up here, via an analysis of a recent French militant form, a circular march called the Ronde Infinie des Obstinés, the "Infinite Rounds of the Stubborn."

In June 2009, three days after arriving in France, I came upon the Ronde in the early evening atop the hill at the heart of Paris's Latin Quarter. It had taken up residence that day in the long cobblestone square beside the iron fence of the Panthéon. As I began walking alongside the protesters, the air cooled, the light faded gray behind forks and tongues of cloud, and the monumental architecture emitted its usual hush. Wreathed in red flags, the Ronde was already established when I arrived, a circle drawn up out of a small crowd of academics from local universities. They were walking around and around the square, one person behind 
the next, carrying banners and backpacks, retracing the same circular path as if aiming at their own past footsteps.

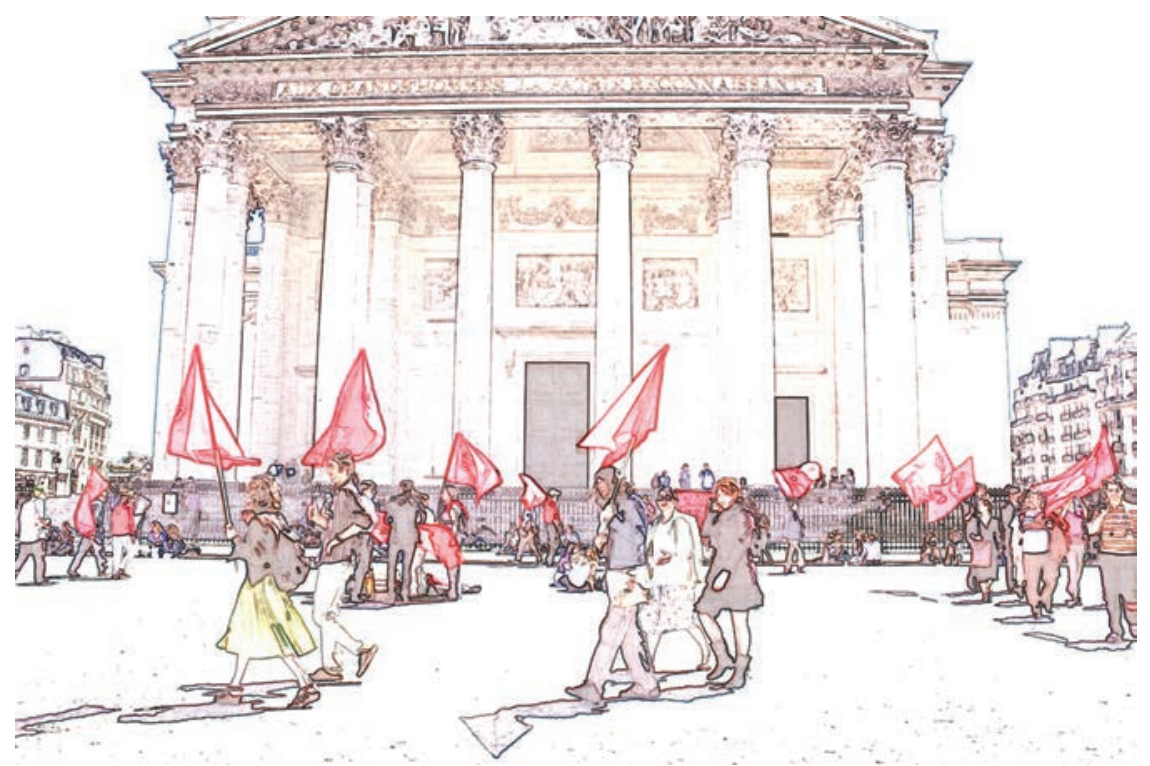

Figure 1. The Ronde beside the Panthéon, June 2009. Sketch by Eli Thorkelson, based on a photograph by Jean-Claude Saget.

The Ronde had initially been launched by French activist academics in March 2009, during Nicolas Sarkozy's five-year term as president of the French Republic. The Sarkozy administration's neoliberalizing civil-service reforms had provoked ire across a wide swath of French public-sector workers, ranging from those employed in hospitals and the justice system to those in public schools and universities, yet substantial protests by students and civil servants had produced scant results. In theory, the Ronde was a strategy of last resort, intended to overcome the Sarkozy administration's antipathy to protest politics. But last resorts are strange places, and even the Ronde's organizers seemed somewhat surprised by the paradoxical nature of their action, as a professor of dance told me during a retrospective interview in 2011:

Professor: I think that it was kind of the last-chance solution. That is, deciding to march in rounds, it was kind of the last gesture we could imagine.

Ethnographer: The stubbornnest thing possible? 
Professor: Yes, but at the same time, it brought hope back to life. Because being together with our colleagues, on an everyday basis, that gave us the courage to continue. . . . We had people come saying it was the last time they were doing it, this thing, which after all was such a, well, an intense site for so many people's encounters. A kind of madness that we had all shared.

Ethnographer: Why a madness?

Professor: Because there was something totally crazy, after all, about marching in rounds for entire days. I mean, it was at once a despairing act and a very joyous act. It seems to me hard to define. It was really between the two, between the madness of marching in rounds, because no one would receive us, speak to us - it was that too. If we couldn't speak to representatives of the ministry, there was nothing left but to show that we existed, to talk to the citizens.

Thus the Ronde constituted a paradox on several levels. Its incoherent affect turned out to be politically useful: the actors' political desperation became practical"brought hope back to life" — by being antipragmatic and antinormative ("crazy"). It instantiated a form of political speech by resorting to a strategy of ritualized corporeality, setting itself apart from other forms of faculty protest-like canceling classes or boycotting paperwork - through its repetitiveness and formality (Bell 1992). And it tried to produce political momentum by enacting a temporal impasse, thus playing on the tension between what Jane Guyer (2007) has called "punctuated" and "enduring" forms of time. As we will see below, the marchers' desired rupture in state temporality never came to fruition, but a glimmer of a new future nevertheless did emerge at the Ronde. Yet I claim in this essay that this was a politics of futurity without hope, of optimism pushed outside of subjectivity to the level of ritualized form. ${ }^{2}$ As we will see, in place of hope, an activist poetics of stubbornness helped keep the Ronde in motion.

As such, it strikes me that the Ronde has something to teach us theoretically about what happens after futures break down, a moment that has preoccupied many recent ethnographers of the present. Its nonsubjective and reparative forms of futurity have further implications for our understanding of prefigurative politics (Graeber 2002) in other recent radicalisms, like Occupy Wall Street, its European predecessor the Indignés, or the 2011 Wisconsin statehouse occupation (Collins 2012; Juris 2012; Rasza and Kurnik 2012; Ruzé 2012). But before we see how 
the Ronde tried to craft a reparative future through rupture, we need to see how futures break down in the first place.

\section{THEORIES OF BROKEN TIME AFTER THE CONTEMPORARY}

Donna Haraway $(2015,161)$, thinking about the proliferation of global ecological crises and the stories we tell about them, has observed that "immense irreversible destruction is really in train, not only for the eleven billion or so people who will be on earth near the end of the twenty-first century, but for myriads of other critters too." But in spite of the ardent debates over the obscure futures of the Anthropocene or, as Haraway and others call it, the Capitalocene, Plantationocene, or even Chthulucene (Haraway et al. 2016; Yusoff 2016; Todd 2015), the empirical fact remains that not every cultural situation is (yet) attuned to its ecological circumstances. Phenomenologically speaking, not everyone's future is in crisis these days. ${ }^{3}$ Ethnographers of dominant economic sectors in the global North, like biotechnology (Rabinow and Bennett 2012; Rabinow and DanCohen 2005), finance (Holmes 2009), or tech entrepreneurs (Marwick 2013), have lately documented futures that seem flush with openness and possibility, however much they may be permeated by a sense of risk or an anxiety about making good calculations. These ethnographers have drawn out of their work a set of deeply affirmative and rather nonlinear categories for apprehending the present and near future. Michael Fischer's (2003, 37) notion of emergence, for instance, foregrounds a present distinguished by "multiple interdigitated temporalities," rooted in a white-collar phenomenology within which "traditional concepts and ways of doing things no longer work." And Paul Rabinow (2008, 3) qualifies the contemporary not just temporally — as a "moving ratio" of the modern and the traditional_ but also politically, insisting that "its goal is not reform or revolution but rather a type of remediation." These kinds of categories help us understand the persistence of temporal effervescence and momentum in a world splintered by precarity (e.g., Millar 2014). As generalizing discourses in contemporary cultural anthropology, they seem to aspire to a certain magnetism, as if expecting to get all sorts of current ethnographic objects to stick to them, and subsuming various modernisms while also breaking with them. ${ }^{4}$

I would argue, however, that ethnographic metacategories like emergence and the contemporary, precisely because of their seeming openness, are missing something, and that this something helps us make sense of the Ronde. ${ }^{5}$ Given that the Ronde was premised on a temporal impasse or closure, it seems inadequate to treat it in terms of affirmative categories that foreclose, in the end, on fore- 
closure itself. The concept of foreclosure has chiefly been developed in psychoanalysis to designate a "primordial casting-out of a fundamental 'signifier' . . . from the symbolic universe of the subject" (Laplanche and Pontalis 1972, 186; cf. Dolar 2012). We can readily socialize this concept, viewing foreclosure as the socio-subjective process by which a given signifier or relationship (a history, a temporality, a form of life, an institution) is cast out of the collective symbolic universe and shuttered. The Ronde Infinie des Obstinés shows us an instance of actors responding to foreclosure in the moment of its perceived arrival; the Ronde made for a "desperate" or "crazy" form precisely because of the actors' overwhelming sense that futurity was getting foreclosed upon - that is, their futurity, good or desirable futurity, the future of the social-democratic university. In this light, to interpret the Ronde as a "contemporary" or "emergent" form, in Rabinow or Fischer's senses, would be tantamount to trying to take a photograph that contained no shadows.

In an effort to help us see the future as not only affirmative (say, as a matter of hopes and aspirations; see Appadurai 2013), I would turn here toward a more depressive body of research, one that casts its gaze farther from the epicenters of capitalist production. In this literature, we find analyses of numerous types of temporal breakdown and impasse, reminding us that the Ronde's phenomenology of closure is not, in fact, so distinctive. Some theorists have undertaken to show how arrows of time are always arrows of ideological misdirection, pointing somewhere other than where they say they go, whether in the realm of military or of heteroreproductive ideologies (Edelman 2004; Masco 2008, 2012). Others have taken a more phenomenological tack, showing how the arrow has broken down into a moment of blockage or discontinuity: thus Lauren Berlant (2011, 199) chronicles "the present as impasse" as "a space of time lived without a narrative genre," while Charles Piot $(2010,19)$ finds in a recent Togolese case that "the gap between a known but rejected past and an unknown though desired future appears unbridgeable.” Piot, Nicholas de Genova (1997), Dominic Boyer (2006), and others have also documented a nostalgia for past futures, a formally distinct configuration in which a present bends back toward the unrealized future of a previous timeline. And in response to the amply documented growth of apocalyptic and millenarian tendencies during the post-Cold War period (Comaroff and Comaroff 2000; Stewart and Harding 1999), Jane Guyer (2007, 409, 417) has remarked on a "strange evacuation of the temporal frame of the "near future"” that is only filled up again by a "punctuated" time of innumerable date-events. 
Future blocked behind a temporal impasse (Berlant 2011):

Present $\longrightarrow$ Impasse $--\rightarrow \ldots$ ?... - - - Future (of Reproduction)

Nostalgia for the future (Piot 2010):

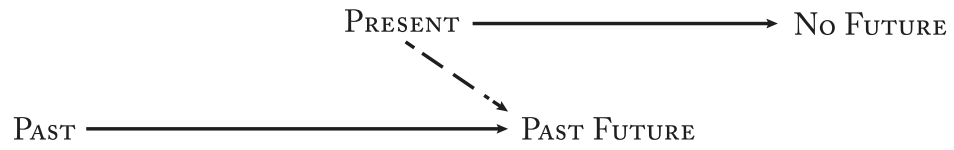

Hatred of the (normative) future (Edelman 2004):

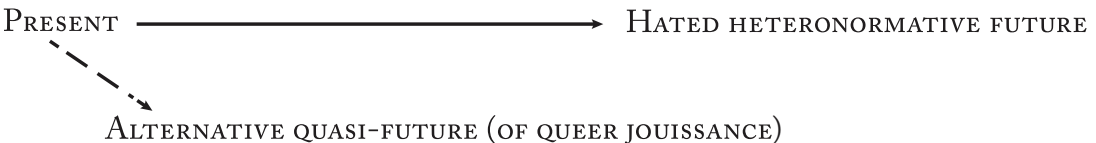

An evacuated near future (Guyer 2007):

Present $\quad$......tetemporal absence.

UNREACHABLE DISTANT FUTURE

Apocalyptic fantasy management (Masco 2012):

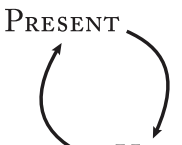

Hermeneutics of

ANXIETY \& ANTICIPATION

Near future refilled with punctuated dates (Guyer 2007):

Present $\longrightarrow$ Date $^{1} \rightarrow$ Date $^{2} \rightarrow$ Date $^{3} \ldots \quad$ Unreachable distant future

Creative presentism (Ringel 2012):

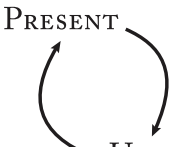

DYstopian

UTOPIAN PRACTICES

OF THE SELF

Video 1 . Some recent theories of temporal breakdown and impasse. 
What does this body of research have in common, in spite of its global scope and evident empirical diversity? Precisely, I think, that it documents how the present can become disconnected from the future, and how the future can thus come to seem unreachable, dystopian, apocalyptic, loathsome, or just lost. In all these cases, the arrow of time has stopped pointing in a good direction, or points in circles, or has become impossible to endorse. (In Edelman's queer theory case, it is not that the future of heterosexual reproduction has broken down in practice, but that its very continuity strikes him as ideologically repulsive.) In short, in all these cases, futurity has been foreclosed upon. And such a foreclosed future was precisely the Ronde's point of departure. I would suggest that we can only understand the Ronde's desperately reparative futurity as a reaction to such an initial moment of temporal blockage and shattering. Let us now see how this reaction was brought into existence.

\section{A UNIVERSITY MOVEMENT RISES AND FALLS}

I found myself walking in circles, in circles, in circles. Staring blankly at the next body in front of me, sensing the footsteps of the body behind me. We were not walking practically, to get somewhere, nor impractically, for the sake of adventure or recreation, but symbolically: "to show that we exist," as my interlocutor put it earlier. We were walking reflexively (see Silverstein 1993): to establish and stabilize the sign of ourselves walking. We inhabited an odd mix of tenses: at once in an absolute present, where time slowed to a halt and the usual course of life was bracketed, but also in the future anterior (Povinelli 2011), so that in the future we would have walked and the government would have had to change course. I walked by myself for a while, surrounded by a big crowd; or struck up conversations with people near me; or overheard things. The other marchers were predominantly French nationals, largely university professors in long dark coats. "It's cold," I said to a woman beside me; she was small, scarved, with brown hair in a steep slope trailing her face. "Yes," she said, "but less cold than I expected.”

We were in the middle of Paris, at the symbolic and spatial heart of the French state apparatus, during a major period of campus protest. In July 2007, the just-elected Sarkozy administration had introduced sweeping national university reforms, led by then-Minister of Higher Education Valérie Pécresse (Caillé and Chanial 2009; Neyrat 2008). These reforms aimed to "autonomize" the traditional centralized system of public universities, which had historically been very inexpensive, open to everyone with a high school diploma, governed by a system 
of council democracy, and chronically underfinanced. Incidentally, these universities also had elected campus presidents, an open-shop union system, and tenured civil-servant status for most staff and faculty. They exhibited considerable stratification by race and class, real problems with sexual harassment, and highly dilapidated facilities (Beaud et al. 2010, 48-63; Hamel 2008; Soulié 2009). The 2007 Sarkozy reforms, in any event, were far from a direct privatization project. Instead, drawing on what is termed New Public Management (Bleiklie 1998; Bruno 2009, 2010; Scott 2010), the project continued a longer French shift toward contractualized, incentive-based, rankings-oriented and entrepreneurial public administration (Boure 2010; Musselin 2004; Vinokur 2008).

The reforms particularly angered the faculty by threatening to increase teaching loads for professors with low publication rates (Ertzscheid 2009), and by trying to fold teacher education into more traditional academic master's programs. ${ }^{7}$ A student protest movement emerged in response to the reforms, and was only stemmed by a ministerial promise not to raise tuition or admission requirements. By the next academic year, 2008-2009, faculty and staff were increasingly angry with the pace of the reforms, the lack of consultation, and the rising structural threats to their traditional social-democratic university model. In February 2009, a massive faculty strike broke out at public universities across the nation. Initially, it consisted of teaching stoppages, symbolic proclamations, and a series of large street demonstrations (manifestations). These events continued throughout the month, but much to the organizers' frustration, the government dismissed their actions, expressing incredulity at the opposition to the necessary "modernization" of public services.

The Ronde Infinie des Obstinés was thus conceived in early March 2009 as a tactic of last resort to overcome the impasse of the movement, reach out to the public, and pressure the ministry. It was organized by a number of faculty at the left-wing University of Paris 8 (Cohen 2010; Soulié 2012). The organizers hailed primarily from the arts and philosophy, and they worked in what I'm told was a collaborative mode: one person invented the name, another proposed the place (on the Place de Grève, "Strike Square," in front of the Paris City Hall), a third suggested the circular structure (borrowed from the Argentinean Mothers of the Plaza de Mayo). The immediate aim was to provoke a response from the minister, and on March 16, they issued an ultimatum: Withdraw the contested reforms, or else, "In a week, that is MONDAY, MARCH 23, at noon, if the government has not taken our demands into account, we will march on the Place de Grève day and night. We will turn day and night to show our stubbornness. We will 
march without end, for we have no intention of giving in.” The ultimatum went unanswered, and on March 23, the Ronde began.

In its first and most important incarnation, it continued from that date until May 4, for just over a thousand hours. Every hour the rondeurs announced the cumulative duration of their march, and a tally of the hours was kept on a large chalkboard. They circulated a fairly thorough user's guide: be prepared for a long walk (with water bottles, rain gear, etc.); don't make too much noise; bring signs or materials for making them; don't forget your identity papers; distribute tracts to passersby; consider organizing "sonic or theatrical punctuations" or readings. Individuals and entire academic departments signed up online to march, and there was often a large crowd of participants, although one older philosophy professor was said to have found himself marching alone, one night at 3 a.m. In any case, as we will see below, its participants described the Ronde as a place of unusual effervescence. While some students at Paris 8 criticized the faculty for leaving campus to dedicate themselves to the Ronde (one called it "bobo," that is, bohemian-bourgeois), others reported developing newfound intimacies with their professors by marching together. In general, the event attracted positive media coverage, at least from left-wing newspapers like Libération and l'Humanité, although the spokesman for Sarkozy's party, the UMP (Union for a Popular Movement), would eventually describe it as the "rounds of the diehards" (ronde des jusqu'auboutistes).

At the thousand-hour mark in May, the rondeurs held a press conference to criticize the government's silence:

Today, as the thousand-and-first hour has come and gone, we have to admit that the government has not wanted to hear a single one of our demands. It has persisted in maintaining its ideological posture, predicated solely on immediate profitability, stigmatizing the risk of thinking as a useless luxury and academic freedoms as mere privileges. Instead of negotiations, this government has preferred to stick with lies and threats. . . . The Infinite Rounds of the Stubborn opposes the politicians' silence with the permanent flux of our speech. And each time we speak, new forms of action are being invented to counter these policies.

The Ronde came to a halt at this point. "If we could have kept going another two weeks, the minister would have had to say something in response," one organizer told me, "but people were at their limit." Publicly, of course, the rondeurs cast the situation in a more positive light: they issued another ultimatum, maintaining 
their demand that the government back down, and if not, promised to march again in June during the elections for the European Parliament. The government again did not back down, and they did march in June, briefly, which was when I first met the Ronde in front of the Panthéon.

After that the movement fell still for the summer. At first public discourse spoke largely of a partial victory; later, a narrative of defeat set in instead. In the fall, a number of activists wanted to continue their movement, but the mass base had disappeared and it took time to set things in motion. A final, scantily attended effort to coordinate a national movement was held in November 2009, and the Ronde was launched again that month, but it dwindled rapidly after the first two meetings. I know the Ronde myself mainly from attending that winter, as the group clung to existence until March 2010. But even when it ceased to attract a mass base, it maintained a fixed political logic, making Parisian urban space into a theater of the future. Let us examine the semiotics of this form in more detail.

\section{PARISIAN SPACETIME AND THE SEMIOTICS OF A FUTURE}

The Ronde's political logic, and its very legibility as a political event, had emerged from its synthesis of two of the most prominent forms of protest in contemporary Paris: the more militant occupation and the more normative street demonstration (manifestation). As the political historian Danielle Tartakowsky (2004, 149) has observed, the manifestation emerged in France toward the end of the nineteenth century, after the defeat of the Paris Commune, as a sort of symbolic replacement for more direct forms of militancy like riots and armed insurrections (cf. Harvey 2003). During the twentieth century, it was standardly employed as a protest tactic by groups across the political spectrum, hinting at official parades like the annual Bastille Day march and at a more militant history of street protest still inscribed in the memories of May and June 1968. ${ }^{8}$ During the time of my 2009-2011 fieldwork, the Parisian street manif - as manifestations were usually called for short — was clearly a well-institutionalized ritual form. It typically involved a linear street procession along a designated route, blocking major avenues with the help of police escorts, and emitting political messages through chants, songs, protest signs, and banners. Its very conventionality seemed to render it ineffective: an officially tolerated ritual of disapproval that seldom interfered directly with the state apparatus. As a result, French campus activists during this period sought to reinvent their forms of political action, trying everything from mock funerals and international countersummits to Academic Pride parades (Brisset 2009). 
These politics were informed, in part, by traditions of direct action and direct democracy that had been elaborated in 1990s altermondialisation ("another world") movements, which had long maintained links to the French academic left (Bodin 2009, 38-41). But the Ronde also continued a more local trend toward occupation as a political tactic. Even as the manifestation declined, the 1990s and 2000s saw the growth of more subaltern politics centered around les sans ("those without"), a category including the out-of-work, undocumented immigrants, and the homeless. While les sans were largely excluded from more normative political forms like the manifestation, the politics of spatial occupation came to constitute an effective means of criticizing the French state even while demanding its recognition. As Daniel Mouchard (2002, 433) put it, this "self-limiting radicalism" often "played with the limits of legality," setting up squats and other forms of civil disobedience.

While they occasionally proved tactically successful, these subaltern protest forms seldom changed the structures of the Parisian political economy. In recent decades, the Paris region (Île-de-France) has seen massive gentrification in the city center, while the outskirts (banlieues, "suburbs") have alternated unevenly between gentrification and racialized immiseration. Public funds fostered neobohemian cultural enclaves (Vivant 2010) and constructed grandiose monuments like the 1996 French National Library (Jordan 2004), but public services like education were threatened by austerity politics, and youth unemployment rose enormously. ${ }^{9}$ In 2005, racial and class tensions broke out into massive riots in the northern banlieues, after two North African teenagers were electrocuted while running from the police. This national event inevitably left traces on activists throughout the nation, including the Ronde's future organizers at the University of Paris 8, one of whom would even write an essay defending riots' emancipatory potential (Lecerf 2007).

While subaltern politics centered on the banlieue, the space of normative political ritual stayed centered on Paris proper. This normative space was divided, generally speaking, into two geographically opposed poles. The space of official state and military rituals remained in the bourgeois western arrondissements, particularly around the Place de l'Étoile and the Place de la Concorde, while leftleaning popular demonstrations typically occurred in the symbolically more working-class eastern quarters, particularly in the triangle formed by RépubliqueBastille-Nation (Tartakowsky 2004, 147). The Ronde strategically placed itself between these two poles, establishing a semipermanent presence in the center of Paris in front of prominent public buildings. Initially at City Hall, it eventually 
moved to the Conseil d'État, the Panthéon, and the Ministry of Higher Education and Research. These sites also situated the Ronde in and around the Latin Quarter, the traditional heart of French academia, and thus hinted spatially at the French quasi-identity between the university and the state.

Yet by synthesizing mainstream forms of strike and demonstration with more militant forms of occupation and direct action, the Ronde's organizers - all of whom worked at a "banlieue university" (Brossat 2003) —also conjoined the political logics of the urban peripheries and the French state center. One might call the Ronde a more respectable, bourgeois type of occupation, one that stayed constantly upright and in motion, like a manif. They thus avoided police harassment of the sort that touched, for instance, the 2011 camps of the Indignés at the Place de la Bastille and the business district of La Défense (Ruzé 2012). In the form of its march, the Ronde sketched out a tripartite spatial structure, producing a new space on the public square and before the state building, a space enclosed by the physical motion of the marchers. This reappropriated space of political mobilization came to intervene between the ambiguous space of the urban mass public and the space of legitimate political power, making visible a political model of applying pressure to the powers that be. Schematically speaking, it was a model of politics in which activists mediated between the state and the people.

Although there was usually some effort to engage with passersby, who stood in for the public at large, the main practical imperative of the Ronde was to maintain the circular form that established the space of the Ronde itself. The bodies of the marchers created a physical barrier that was also a symbolic barrier, enclosing a mostly empty space in the center that held banners and marchers' backpacks. This physical barrier required constant patching: when gaps sprung up in the circle, people would hurry ahead to close them, and during the thousandhour period in 2009, an elaborate scheduling system maintained temporal continuity, with different university departments signing up online to march during certain slots. This intense emphasis on the internal structure of the Ronde itself created an unusual social effervescence. The overwhelmingly dominant activity at the Ronde was simply talking to the other marchers. People would talk about the pressures of their work, about current events, about the cops watching; they would gossip about their colleagues, critique American universities, give me advice about how to deal with my landlord, and talk about the sorry state of the French left. This created a sense of social and political belonging: months afterward, people I barely recognized would say, "Oh yes, I know you from the Ronde." 

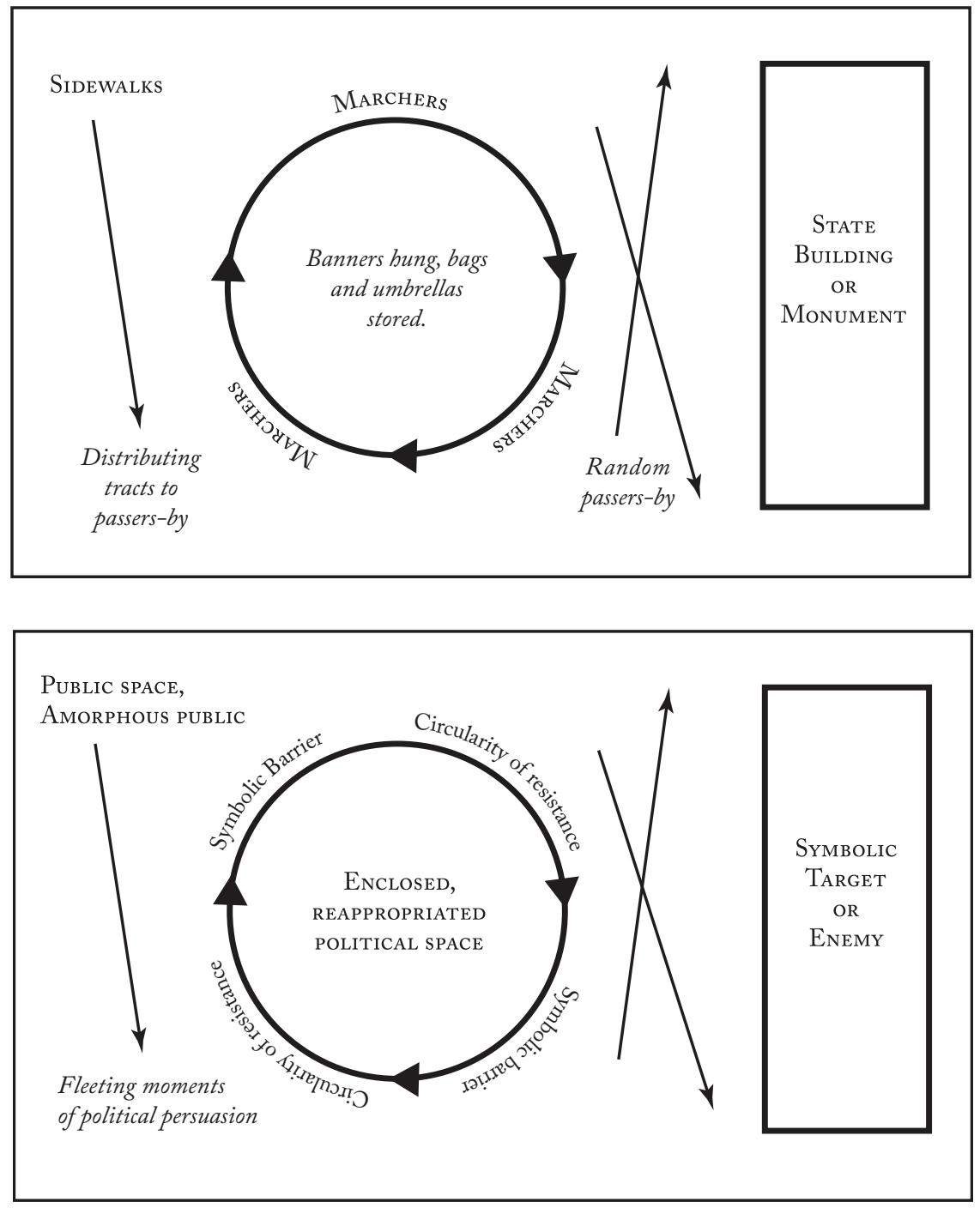

Figure 2. A schematic diagram and interpretation of the Ronde's spatial structure.

We will see below how this space of sociability prefigured the content of the future university world that the marchers wanted. But sociability was not perceived as sufficient, since sociability by itself did not serve to accomplish the strategic objective - to stop the government's university reforms and thereby to reconnect the present to the future. An intermediate semiotic apparatus was needed, one that wove together a practice of corporeal stubbornness with an image of redirected time. In semiotic terms, the Ronde's circular form came to 
constitute a spatial icon that made the physical and geometrical into signs of the affective, political, and temporal. This circle was never literally visible, but rather raggedly traced out in space by the motion of the marchers' bodies. The circularity of marchers' paths was a given; the circle as such was something only posited. Yet as a collectively posited spatial figure, the circle worked as an icon of the marchers' stubbornness. Just as stubbornness implies an unconditional, seemingly infinite tenacity and determination, so a circle never comes to an end.

\begin{tabular}{|l|l|}
\hline Sign and its relation to its object & Medium of signification \\
\hline $\begin{array}{l}\text { 1. People walking in circular but irregular } \\
\text { trajectories - are icons and indexes of }\end{array}$ & Physical, corporeal sign \\
\hline 2. A circle - which is iconic of & Geometrical \\
\hline $\begin{array}{l}\text { 3. The stubbornness of the marchers -is an } \\
\text { index and an icon of }\end{array}$ & Affective/emotional \\
\hline $\begin{array}{l}\text { 4. The project of resistance to government } \\
\text { university reforms - which is an index of }\end{array}$ & Political \\
\hline $\begin{array}{l}\text { 5. The utopian desire for an alternative, } \\
\text { “democratic" future }\end{array}$ & Temporal (utopian) \\
\hline
\end{tabular}

Table 1. Levels of signification in the Ronde.

This stubbornness in turn served as an icon and an index of the university movement's political project. Stubbornness was both cause and expression of a political threat to the government's university reforms, an icon of a politics of total resistance. According to the Ronde organizers themselves, this politics of resistance was not an end in itself, but rather a means to, and at least hopefully an index of, a utopian commitment to an alternative future for the university. The Ronde's flier proclaimed: "We teachers, researchers, staff and students . . . are devoted to preserving and restoring a democratic future for the institution"a future, moreover, "that cannot be dictated by short-term economic needs."10

There was a paradox here, but it was a strategically viable one: that stubbornness and temporal blockage would work to mobilize the universities, to prove their obstinacy to the government, and ultimately to point the future in a new direction. As such, this was a rather nonlinear logic of the future, contrasting strongly with the top-down state modernization telos the Sarkozy government sought. ${ }^{11}$ From the government's perspective, state action was essentially linear, with ministerial decrees flowing out across the university system and pointing 


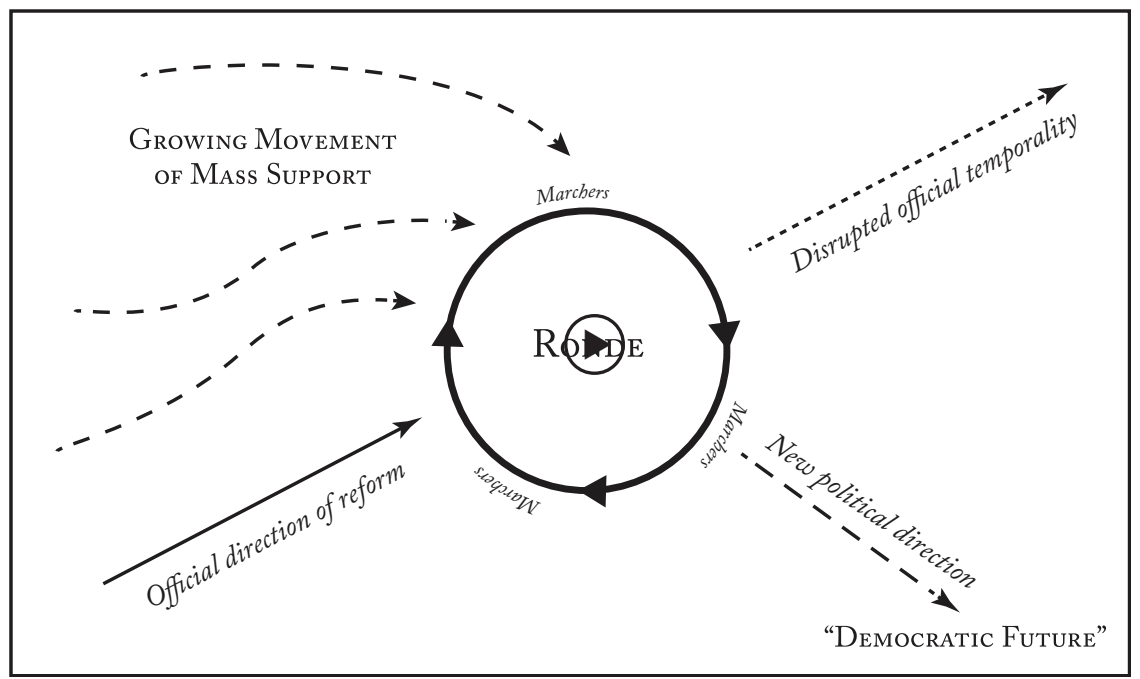

Video 2. A schematic diagram of disruption in official temporality.

history in the chosen direction. But since faculty activists at the Ronde did not have the means to impose their own (opposing) temporality directly, they tried instead to trump a linear temporality with a circular one. In theory, their circular march could create a knot of political energy and stubbornness, interrupt the state's university reform project, and ultimately change the dominant direction of politics.

These efforts to redirect time toward a democratic future did work in practice, to a degree, at least. The stubbornness of the Ronde had a vital performative dimension, projecting political agency and strength, visibility, and constancy. In strictly strategic terms, the Ronde's performativity and the ensuing media attention did succeed in contributing political momentum to the 2009 movement. This analysis would nevertheless be incomplete without a closer look at the work of stubbornness (obstination), which always remained a fragile, compensatory form.

\section{STUBBORNNESS AS COMPENSATORY FORM AND PREFIGURATIVE CONTENT}

I watched as the marchers had innumerable repetitive conversations, or at times had nothing to say to each other, as the same dusk fell on the same square again and again. I would listen to the marchers chant a certain chant: "Qu'est-ce qu'on veut? Le retrait! Retrait de quoi? La LRU!" ("What do we want? Withdrawal! 
Withdrawal of what? The LRU [university reform law]!”) The voices would echo intermittently across the square, the sky dimly visible behind the red flags with their circular icons.

Stubbornness at the Ronde came to compensate for the lack of hope that many of the marchers expressed, exemplifying an attachment to the future that as I suggested at the outset of this essay and now want to demonstrate - does not figure as hope or affirmation. One night, I found myself talking to a science professor. After lamenting how French science education was getting watered down and jobs were getting cut, she denounced the baneful American university model, much criticized in France on account of its ostensible policy influence. "I believe in public education, equal education regardless of your background. But you Americans have private universities, which we're against. The question of a public university isn't even intelligible over there . . ." As the Ronde came to an end that night, I asked her where the movement got its political hope. "It's less about hope, more about it being impossible to give up after everything they've done so far," she said. "It would just be too much to give in." I asked if I'd see her at the next Ronde; she wasn't sure she'd come.

At the Ronde, I found it virtually impossible to get people to say that they were optimistic. A relationship to the future existed that actors could only express by walking, and were unable to put in words. While the bodies of the marchers continually traced out their political commitments, I found that their stances could be put in question if you said the wrong thing or asked for too much reflection. By the end of the winter of 2010, I had to stop asking people about the sources of their political hope, because the question elicited too much despair. "I don't do politics out of hope," said one graduate student, sighing. "Voilà, as time went on they pushed through their decrees, and little by little we figured out that, well, it wasn't gonna happen," a music professor said. Yet she continued to march in the Ronde, as if in spite of her own analysis. It seemed at times a very inarticulate utopianism, one almost ashamed. As if to say: I'm still marching, but don't push me to explain myself too closely.

What stood in for a discourse on hope was a discourse on keeping going, framed as a discourse on stubbornness - a feeling that the winter 2010 rondeurs more freely professed. It was a common occurrence that winter for someone to wonder aloud whether the Ronde should be stopped. The standard response was: no, let's keep going at least a little while longer. I'm still stubborn (“J'suis toujours obstiné(e)"). Through conversations like this, collective attachments to an alternative future were maintained in a desubjectified form. The marchers' stubborn- 
ness became a public, collective construct that sidestepped individual doubts, externalizing and formalizing their political feelings and attachments. Once the Ronde was established, in a sense the marchers no longer needed to say or even feel they were stubborn, because the very form of their action already expressed their stubbornness. This stubbornness was embedded in the very name of the Infinite Rounds of the Stubborn. The three terms - ronde, infinie, and les obstinés were in context almost synonymous, each encoding the same message of "not stopping," so that the very name showed obstinacy through repetition. Stubbornness thus turned out to facilitate a whole activist poetics, affording a performative efficacy that more anodyne signifiers like "hope" might not have provided.

Nevertheless, as evidenced by the constant proposals to give up, stubbornness proved itself quite fragile, and the infinitude of the rounds was decidedly finite. According to the professor of dance I interviewed, even at its height in spring 2009, the Ronde had never felt stable as a form:

Professor: What I do know is that people regularly asked the question: are we continuing or not, eh?

Ethnographer: So it wasn't at the start [in March] that you decided to do the thousand hours?

Professor: Oh no. Not at all, eh? No, when we started, we didn't even know if we were going to keep it going twenty-four hours.

Ethnographer: Oh, yeah?

Professor: No, but it's true. We didn't know if we'd be capable of that. I would say, each day was a victory. Every twenty-four hours, it was like, hey, we've done it, yeah, it worked. At the end of a week, we were already pretty stunned that it had-because it was working, definitely, thanks to the faculty at Paris 8, but it could only keep working if other campuses showed up too. And even at Paris 8, not all the faculty were on strike. . . . [When we got to April] there were the Easter vacations. It was the first decisive [critique] moment. . . . In the end, it continued. So we succeeded, like! But it was hard. . . . Do we stop? Because there was no one but Paris 8 still marching? Only Paris 8? And the other universities had gone back to class. But at the same time, no one wanted to stop. It's quite strange, because people didn't want to stop, but at the same time, they were incapable of saying, I'll show up for a day.

Stubbornness was thus both a generative and a tenuous form. As we saw in the previous section, it powered a political semiotics that pointed decisively toward 
an alternative future, and as we see here, it kept the action going in spite of widespread doubt and despair. My analysis can now take one last step, showing how stubbornness also shaped the content of the Ronde's alternative future. Even as the form of their action broadcast the marchers' politics on repeat, as it were, it left them free to build an informal space of conversation and sociability, which prefigured the democratic future they sought.

First, through its profusion of open-ended conversations, the Ronde modeled horizontality and egalitarianism among its participants, enacting an academic community not based on bureaucratic hierarchy. As an April 28, 2009 pamphlet remarked, "This ronde is a living demonstration of the collegiality on which the university is founded. . . . This ronde certifies that the university is nothing without the community it emerges from." Second, this community was framed as being outside the market (or at most, adjacent to it). Thus while the marchers often partook of the nearby cafés and restaurants before and after marching, the march itself was always set firmly apart from commercial transactions. In this, the Ronde mirrored its own idealized image of the university; "the university is not a corporation" ("l'université n'est pas une entreprise") was a common slogan. And finally, the Ronde exemplified a community in which belonging was an intrinsically political activity, in which one's mere presence sent a political message. Stubbornness was framed as a key component of this political identity, reframing academics as citizen-activists in direct contact with the public, rather than as "human resources."

In sum, we might say that the Ronde's "democratic future" was imagined as an egalitarian academic community, centered on an open space of conversation and free association, set apart from markets, commodities, and corporations (though not opposing these as such), and organized through political voluntarism, rather than bureaucratic hierarchy. Each of these parameters was, in effect, a symbolic negation of what the university system was becoming under the Sarkozy government's reforms - in protesters' eyes, at least. ${ }^{12}$ In spite of the fragility of its form, the Ronde continued to prefigure this future, on and off, for more than a year, before coming to a final halt in March 2010. "We were spreading ourselves too thin," one of the organizers told me afterward, describing how she had gone back into activism on her campus.

But curiously, even when the Ronde finally came to its last day, on March 29, 2010, it proved all but impossible to bring it to an end. First the march came to a stop and people gathered around. Then they had champagne. Then they stood around and talked. A few people left, but most of them lingered and talked some 
more. It was as if it was impossible for people to leave the scene of their stubbornness, impossible to leave the scene of their imagined alternative future. People smiled, looked away, sipped their drinks. They left slowly, one by one, the self-appointed photographer taking photos of the person who took down the last banner. The Ronde wasn't said to be over; it was said to have been "put in orbit." The photographer, Jean-Claude Saget, shared his photos online with the caption: "Our stubbornness persists — and will show itself in other Rondes!" The future, it seemed, was a difficult thing to give up. ${ }^{13}$

\section{PREFIGURATION, OPPOSITION, AND REPAIR}

What happens to the future if modernist temporalities become more obscure and more distant, hidden at times behind claims that we are post-history or postideology, drowned out at other moments by an eco-apocalyptic "narrative of imagined endings" (Yusoff 2016, 22)? Without venturing a general account here, the Ronde hints at a landscape of ordinary futures constantly getting smashed and reconstituted, disconnected and reconnected, repaired in the face of foreclosure. Not all repair work is successful, of course, but if we can talk about conversational repair or reparative reading (Schegloff, Jefferson, and Sacks 1977; Sedgwick 2003), surely we can talk about reparative temporalities as well?

If so, the lesson of the Ronde would be that a reparative futurity need not be- - and in some cases must not be-solely a matter of subjective stance. What kept the Ronde going, I have argued, was its preference for walking over talking, its use of ritualized motion to work around its participants' lack of hope. Here I would concur with Dominic Boyer and Alexei Yurchak's (2010, 212) argument that a subversive politics of form can emerge precisely when it becomes ineffective to "challeng[e] the language of authoritative discourse directly." I would modify their conclusion, though, on one major point. Boyer and Yurchak (2010, 213) view their case - a type of media satire called stiob, where the form of dominant discourse gets mimicked perfectly, even while the content is made ridiculousas an instance of "contexts where pure opposition may be inefficient, counterproductive, or impossible." But opposition through formal innovation, as the Ronde reveals, is not a less pure type of opposition than conventional street marches or manifestos. ${ }^{14}$ Rather, it is a moment in which opposition itself gets refashioned and remediated.

The theoretical upshot of the Ronde, then, is chiefly that opposition through form can constitute a reparative temporality. This thought, in turn, allows us to revisit the notion of prefiguration, which has become so central to analyses of 
recent radical politics (van de Sande 2015; Yates 2015). As we saw, the Ronde's ritualized form spared its participants from having to inhabit political hope directly, while freeing them to enact a version of an idealized academic community. Earlier, I called this a way of prefiguring the content of their democratic future. But their sort of prefiguration was more ambivalent than David Graeber's (2002, 72) familiar image of the means joyfully enacting the ends, such that direct action leaves one's "sense of human possibilities . . . profoundly transformed." Direct action, Graeber $(2002$, 62) tells us, rejects "a politics which appeals to governments to modify their behaviour, in favour of physical intervention against state power in a form that itself prefigures an alternative." Of course, the Ronde's politics were substantively more social-democratic than anarchist. Yet what we saw at the Ronde formally resembled what Graeber describes: an opposition to state power that is at once a means of prefiguring an alternative future.

Other analysts of radical politics have nevertheless emphasized that Graeber's utopian type of prefiguration is actually somewhat rare: it turns out to be unusual for activists to evoke the future with any concreteness. Maple Rasza and Andrej Kurnik (2012, 252), in a study of Occupy Slovenia, propose that, "rather than seeing direct action, as Graeber has described it, as the 'defiant insistence on acting as if one is already free' or expressing hope in an eventual telos of freedom, activists around Occupy Slovenia are engaging in a messy, and, some activists stressed, never-ending liberation struggle.” Stine Krøijer (2010, 149) argues that, for anti-NATO protesters in Strasbourg, the future could appear only very abstractly as "the otherwise," in protest moments where temporalities were always multiple and bodies were pressed together. "This figuration [of the future] is not a pre-figuration . . . not an anticipation or foreshadowing of a future to come," she argues, but "a giving of bodily form to the indeterminable." Finally, in Felix Ringel's $(2012,174,178)$ study of East German anarchists who are "decorating the basement with cardboard machine guns" for an antiauthoritarian party, he finds that their "creative presentism" was quite critical of "dystopian notions of the distant future." At stake here, I think, is whether prefiguration is a good general category for analyzing time and utopian aspiration in contemporary radical politics; Kroijer, Ringel, and Rasza and Kurnik's cases clearly show that prefiguration as such is not ubiquitous in this milieu.

One might at this juncture observe that prefiguration is more an influential model for radical politics than an adequate model of them. But what, then, would be the general structure of radical protest temporality? Prefiguration, rather than being foundational, may only be an instance of an affirmative moment in the 
dialectics of temporal repair. Reconnected futurity is based, at least in the Ronde's case, both on a moment of negation (not that future, as opposed to no future) and on a moment of deictic reorientation (the arrow of time should point this way instead; the future should look like this; there should be a future). And far from divulging a primordial affirmation or hopefulness, reconnected futurity is fundamentally reparative and compensatory. Rather than appearing ex nihilo, it emerges from moments of temporal foreclosure (the reform of a university system, the death of an ideal, etc.) that it hopes to forestall. To be reparative and compensatory is, however, not a bad thing if one accepts that no one is sui generis or outside history. Indeed, if the Ronde Infinie des Obstinés had a moral for academics outside France, it might well be this: that being reparative can sometimes be the closest thing possible to a radical gesture. As it shows us how to be reparatively political by generating new forms of sociability within the academic world, the Ronde reminds us that "our stubbornness persists" - and that this is no bad thing.

\begin{abstract}
When social actors find themselves at an impasse, perceiving their futures as threatened, how can they respond? If their futures can get broken or interrupted, can they subsequently be reconnected or repaired? If yes, how? Here, I consider an ethnographic case of reconnected futurity drawn from French protest politics: the 2009-2010 Ronde Infinie des Obstinés, or "Infinite Rounds of the Stubborn.” Opposing Sarkozy-era neoliberal university reforms, the Ronde sought to instrumentalize its temporal and political impasse, shifting its relation to the future out from the register of subjectivity and into the register of ritual motion. By situating the Ronde within the fabric of Parisian political space, I show how it synthesized the politics of occupation with the politics of marching, hopelessness with stubborn endurance, the negation of state temporality with the prefiguration of an alternative future. I conclude by reflecting on the place of temporal repair in relation to recent forms of prefigurative radicalism. [futures; political protest; higher education; ritualization; subjectivity; France]
\end{abstract}

\title{
NOTES
}

Acknowledgments This essay owes its existence to the remarkable warmth and hospitality I found at the Ronde and among the rondeurs, who I hope will recognize themselves in these pages. I am also deeply indebted to Svetlana Borodina, Victor Giménez Aliaga, and Anneli Joplin, who realized the animated diagrams. I am grateful to Steve Coleman for organizing the session at the European Association of Social Anthropologists meeting where the analysis was initially presented, and to Lauren Berlant, Joshua Reno, Davydd Greenwood, Tracey Rosen, Lashandra Sullivan, Eric James Triantafillou, and the Cultural Anthropology reviewers and editorial collective for their perceptive comments.

1. Without giving a formal definition of a future in this article, I would simply note that 
I do not think of futures (as a cultural form) solely as a matter of representation, rhetoric, or genre. Instead, revising Jean-Paul Sartre's view that human being is fundamentally constituted by projects and projections that may elude representation (Thorkelson 2014), I will say that any project of social production and reproduction entails a specific form of futurity toward which social actors are carried, though not without a degree of agency in the process. When this form of futurity encounters resistance from other social actors' projects, political conflicts over the form and content of the future readily ensue.

2. As Catherine Bell $(1992,186)$ has observed, ritualization as a social strategy can be decoupled from subjectivity or consciousness. Thus "ritualized activities specifically do not promote belief or conviction. On the contrary, ritualized activities afford a great diversity of interpretation in exchange for little more than consent to the form of the activities." In the present ethnographic case, we can go even farther: at the Ronde, the disjuncture between subjective conviction and ritual form proved necessary and productive.

3. As Janet Roitman (2014) rightly observes, crisis is a historically specific epistemic form whose invocation can serve as a form of transcendental alibi for those who wish to summon it. Given the specificity of this form, one would not expect that crisis (qua narrative) could set in everywhere, as the ethnographic data indeed demonstrates. Yet Roitman's focus on conceptual genealogy tends to occlude a more phenomenological, affective or reproductive reading of "crisis ordinariness" (Berlant 2011, 81-82). In the protest case I consider here, crisis designated less a transcendental classifier than a cluster of affects (anger, stubbornness, hopelessness) that was sensed more or less collectively and inchoately, emerging from life amid a set of neoliberal reforms whose effects, I argue elsewhere, were largely lived in advance.

4. Both Fischer and Rabinow are experts at assimilating certain modernisms while still organizing their discourse structurally around outright rejections of things that get framed as past. While Rabinow is quite sympathetic to certain aesthetic modernisms, his rejection of "reform or revolution" clearly indexes a former era's characteristic politics. And Fischer $(2007,3)$ frames contemporary anthropology in an almost evolutionary perspective - for instance, he historicizes culture theory in terms of seven quasi-epochs (a "historically layered growth of specifications and differentiations") that build on but also replace each other over time. While Fischer acknowledges that contemporary senses of novelty are in no way new, he constantly polices the boundaries between past and present. Describing contemporary anthropology, he comments that "[its] cross-cultural perspective is no longer a binary logic (us/them, civilized/primitive, Europe/the rest, Christian/savage, developed/underdeveloped), but, like most contemporary information matrices, a constantly comparative and difference-scanning perspective" (Fischer 2003, 13). The move that strikes me as typical here is to subsume past distinctions into some more capacious theoretical system, while also differentiating us from a past whose "binary logic" ironically needs rejecting. As Susan Stanford Friedman $(2001,299)$ remarks about modernisms in general, there is "a transferential process in which people become caught in a repetition of the unresolved contradictions present and largely repressed in modernity itself."

5. I would certainly not argue that nothing is emergent or in "flux" in a broadly Deleuzian sense, nor that there is no "vagueness" or "unfinished quality of the ordinary" (Stewart 2007, 127; cf. Pandian 2012). Rather, in my view, emergence and openness become problematic when they are (ironically) promoted to the status of privileged ethnographic objects, general theories of the present, or "totalizing categories" (Hodges 2008, 403).

6. Most of the marchers hailed from public universities in the Paris region, though some of the grandes écoles were also represented, particularly social scientists from the École des Hautes Études en Sciences Sociales. As the Ronde dwindled in the fall of 2009 and the winter of 2010, its composition became more exclusively Paris 8 faculty.

7. See the extensive documentation by Sauvons l'Universite collected at http://www. sauvonsluniversite.com/spip.php?article762. 
8. One tract from May 24, 1968 commented explicitly on a potential for political unity that could only be realized in the street: "The riot police are already trying to cross the picket lines, each isolated from the next and thus vulnerable. In the street, we can show them an irresistible front" (Mouvement du 22 mars 1968, 160).

9. Over the past thirty years, youth unemployment was at its lowest in 1989 at 15 percent, reaching its highest numbers in 2013 with 23.9 percent.

10. Of course, stubbornness turned out to be ambiguous: the government viewed it as a symptom of a pathological refusal of all reform, a symptom of a sort of leftist conservatism. But here we are taking this political event on its own terms.

11. As numerous European analysts have noted, university neoliberalization often involves a paradoxical demand that universities be more "autonomous" only to better serve strategic goals set by the state (Vinokur 2008; Wright and Ørberg 2008).

12. To be clear, I aim in this article to reconstruct the logic of a protest against the Sarkozy university reforms, not to offer my own assessment of these policies.

13. Lauren Berlant has pointed out to me that what was being given up here was an impasse, but I would still observe that the political impasse in which the 2009 movement survived was itself construed as a symbol of a pathway to a possible future, a sign of an open futurity. In this sense, giving up on the Ronde was indeed giving up on the future, in ideological terms.

14. In Boyer and Yurchak's (2010) case study of the Yes Men, for instance, it is manifest that the activist group was in no way indirect about their basic opposition to their protest targets (the World Trade Organization, Dow Chemicals), even though they certainly mediatized their opposition in a new way.

\section{REFERENCES}

Appadurai, Arjun

2013 The Future as Cultural Fact: Essays on the Global Condition. New York: Verso.

Beaud, Olivier, Pierre Encrenaz, Marcel Gauchet, François Vatin, and Alain Caillé

2010 Refonder l'université: Pourquoi l'enseignement supérieur reste à reconstruire. Paris: La Découverte.

Bell, Catherine

1992 Ritual Theory, Ritual Practice. New York: Oxford University Press.

Berlant, Lauren

2011 Cruel Optimism. Durham, N.C.: Duke University Press.

Bleiklie, Ivar

1998 "Justifying the Evaluative State: New Public Management Ideals in Higher Education." European Journal of Education 33, no. 3: 299-316. http://www. jstor.org/stable/1503585.

Bodin, Romuald

2009 "Les conditions de la révolte." In La protestation étudiante: Le mouvement du printemps 2006, edited by Bertrand Geay, 19-42. Paris: Raisons d'Agir.

Boure, Robert

2010 "De l'evaluation collegiale a l'evaluation a dominante gestionnaire: Le cas de l'AERES." Communication et Organisation 38: 41-63. http://dx.doi.org/10. 4000/communicationorganisation. 1391.

Boyer, Dominic

2006 "Ostalgie and the Politics of the Future in East Germany." Public Culture 18, no. 2: 361-81. http://dx.doi.org/10.1215/08992363-2006-008.

Boyer, Dominic, and Alexei Yurchak

2010 "American Stiob: Or, What Late-Socialist Aesthetics of Parody Reveal about Contemporary Political Culture in the West.” Cultural Anthropology 25, no. 2:

Brisset, Claire-Akiko, ed. 179-221. http://dx.doi.org/10.1111/j.1548-1360.2010.01056.x.

2009 L'Université et la recherche en colère: Un mouvement social inédit. Broissieux, France: Editions Croquant. 
Brossat, Alain

2003 “Une université de banlieue.” Passant, no. 44. http://www.passant-ordinaire. $\mathrm{com} /$ revue/44-529.asp.

Bruno, Isabelle

2009 “The 'Indefinite Discipline' of Competitiveness: Benchmarking as a Neoliberal Technology of Government.” Minerva 47, no. 3: 261-80. http://dx.doi.org/ 10.1007/s11024-009-9128-0.

2010 “2010: L’Odysée de 'l'espace européen de la connaissance.' Comment la stratégie de Lisbonne gouverne les politiques d'enseignement supérieur.” Économies et Sociétés, no. 43: 535-58.

Caillé, Alain, and Philippe Chanial, eds.

2009 “L’Université en crise: Mort ou resurrection?" Revue du M.A.U.S.S., no. 33.

Cohen, Paul

2010 "Happy Birthday Vincennes! The University of Paris-8 Turns Forty." History

Collins, Jane Workshop Journal 69, no. 1: 206-24. http://dx.doi.org/10.1093/hwj/dbp034.

2012 “Theorizing Wisconsin’s 2011 Protests: Community-Based Unionism Confronts Accumulation by Dispossession." American Ethnologist 39, no. 1: 6-20. http:// dx.doi.org/10.1111/j.1548-1425.2011.01340.x.

Comaroff, Jean, and John L. Comaroff

2000 "Millennial Capitalism: First Thoughts on a Second Coming." Public Culture 12, no. 2: 291-343. http://dx.doi.org/10.1215/08992363-12-2-291.

de Genova, Nicholas

1997 “The Junkyard of Futures Past.” Anthropology and Humanism 22, no. 2: 171-79. http://dx.doi.org/10.1525/ahu.1997.22.2.171.

Dolar, Mladen

2012 “Hegel and Freud.” e-flux, no. 34. http://www.e-flux.com/journal/34/68360/ hegel-and-freud.

Edelman, Lee

2004 No Future: Queer Theory and the Death Drive. Durham, N.C.: Duke University Press.

Ertzscheid, Olivier

2009 "Modulation de service: un décret au service d'une décrépitude annoncée." In L'Université et la recherche en colère: Un mouvement social inédit, edited by ClaireAkiko Brisset, 175-90. Broissieux, France: Editions Croquant.

Fischer, Michael M. J.

2003 Emergent Forms of Life and the Anthropological Voice. Durham, N.C.: Duke University Press.

2007 “Culture and Cultural Analysis as Experimental Systems.” Cultural Anthropology 22, no. 1: 1-65. http://dx.doi.org/10.1525/can.2007.22.1.1.

Friedman, Susan Stanford

2001 "Definitional Excursions: The Meanings of Modern/Modernity/Modernism." Modernism/Modernity 8, no. 3: 493-513. http://dx.doi.org/10.1353/mod. 2001.0062 .

Graeber, David

2002 “The New Anarchists.” New Left Review 13: 61-73. https://newleftreview.org/ II/13/david-graeber-the-new-anarchists.

Guyer, Jane I.

2007 "Prophecy and the Near Future: Thoughts on Macroeconomic, Evangelical, and Punctuated Time.”American Ethnologist 34, no. 3: 409-21. http://dx.doi.org/ 10.1525/ae.2007.34.3.409.

Hamel, Christelle

2008 "Le traitement du harcèlement sexuel et des discriminations à l'université: La France n'est toujours pas en conformité avec le droit européen." Mouvements, nos. 55-56: $34-45$. 
Haraway, Donna

2015 “Anthropocene, Capitalocene, Plantationocene, Chthulucene: Making Kin.” Environmental Humanities 6: 159-65. http://dx.doi.org/10.1215/220119193615934.

Haraway, Donna, Noboru Ishikawa, Scott F. Gilbert, Kenneth Olwig, Anna L. Tsing, and Nils Bubandt

2016 "Anthropologists Are Talking_About the Anthropocene." Ethnos 81, no. 3: 535-64. http://dx.doi.org/10.1080/00141844.2015.1105838.

Harvey, David

2003 Paris, Capital of Modernity. New York: Routledge.

Hodges, Matt

2008 "Rethinking Time's Arrow: Bergson, Deleuze and the Anthropology of Time." Anthropological Theory 8, no. 4: 399-429. http://dx.doi.org/10.1177/ 1463499608096646.

Holmes, Douglas R.

2009 "Economy of Words." Cultural Anthropology 24, no. 3: 381-419. http://dx. doi.org/10.1111/j.1548-1360.2009.01034.x.

Jordan, David P.

2004 "Haussmann and Haussmannisation: The Legacy for Paris." French Historical Studies 27, no. 1: 87-113. http://dx.doi.org/10.1215/00161071-27-1-87.

Juris, Jeffey S.

2012 "Reflections on \#Occupy Everywhere: Social Media, Public Space, and Emerging Logics of Aggregation." American Ethnologist 39, no. 2: 259-79. http:// dx.doi.org/10.1111/j.1548-1425.2012.01362.x.

Krøijer, Stine

2010 "Figurations of the Future: On the Form and Temporality of Protests among Left Radical Activists in Europe." Social Analysis 54, no. 3: 139-52. http:// dx.doi.org/10.3167/sa.2010.540309.

Laplanche, Jean, and J.-B. Pontalis

1972 “Appendices: Vocabulaire de la psychanalyse.” Yale French Studies no. 48: 179202. http://dx.doi.org/10.2307/2929628.

Lecerf, Eric

2007 “Les voies tordues de l'émancipation." International Journal of Francophone Studies 10, nos. 1-2: 121-38. http://dx.doi.org/10.1386/ijfs.10.1and2.121/1.

Marwick, Alice E.

2013 Status Update: Celebrity, Publicity, and Branding in the Social Media Age. New Haven, Conn.: Yale University Press.

Masco, Joseph

2008 “'Survival is your business': Engineering Ruins and Affect in Nuclear America.” Cultural Anthropology 23, no. 2: 361-98. http://dx.doi.org/10.1111/j.15481360.2008.00012.x.

2012 “The End of Ends.” Anthropological Quarterly 85, no. 4: 1107-24. http:// Millar, Kathleen dx.doi.org/10.1353/anq.2012.0061.

2014 "The Precarious Present: Wageless Labor and Disrupted Life in Rio de Janeiro, Brazil.”Cultural Anthropology 29, no. 1: 32-53. http://dx.doi.org/10.14506/ ca29.1.04.

Mouchard, Daniel

2002 “Les mobilisations des 'sans' dans la France contemporaine: L'émergence d'un 'radicalisme autolimité'?" Revue Française de Science Politique 52, no. 4: 425-47.

Mouvement du 22 mars http: / /dx.doi.org/10.3917/rfsp.524.0425.

1968 “De Gaulle à la porte!” Le Mouvement Social, no. 64: 160-61.

Musselin, Christine

2004 The Long March of French Universities. New York: RoutledgeFalmer. 
Neyrat, Frédéric

2008 "Enseignement supérieur: La grande transformation?" Mouvements, nos. 55-56: 62-71. http://dx.doi.org/10.3917/mouv.055.0062.

Pandian, Anand

2012 "The Time of Anthropology: Notes from a Field of Contemporary Experience." Cultural Anthropology 27, no. 4: 547-71. http://dx.doi.org/10.1111/j.15481360.2012.01161.x.

Peebles, Gustav

2008 "Inverting the Panopticon: Money and the Nationalization of the Future." Public Culture 20, no. 2: 233-65. http://dx.doi.org/10.1215/08992363-2007-025.

Piot, Charles

2010 Nostalgia for the Future: West Africa after the Cold War. Chicago: University of Chicago Press.

Povinelli, Elizabeth A.

2011 Economies of Abandonment: Social Belonging and Endurance in Late Liberalism. Durham, N.C.: Duke University Press.

Rabinow, Paul

2008 Marking Time: On the Anthropology of the Contemporary. Princeton, N.J.: Princeton University Press.

Rabinow, Paul, and Gaymon Bennett

2012 Designing Human Practices: An Experiment with Synthetic Biology. Chicago: University of Chicago Press.

Rabinow, Paul, and Talia Dan-Cohen

2005 A Machine to Make a Future: Biotech Chronicles. Princeton, N.J.: Princeton University Press.

Rasza, Maple, and Andrej Kurnik

2012 “The Occupy Movement in Žižek's Hometown: Direct Democracy and a Politics of Becoming." American Ethnologist 39, no. 2: 238-58. http://dx.doi.org/ 10.1111/j.1548-1425.2012.01361.x.

Ringel, Felix

2012 "Towards Anarchist Futures? Creative Presentism, Vanguard Practices, and Anthropological Hopes." Critique of Anthropology 32, no. 2: 173-88. http:// dx.doi.org/10.1177/0308275X12437979.

Roitman, Janet

2014 Anti-Crisis. Durham, N.C.: Duke University Press.

Ruzé, Emmanuel

2012 “Des réseaux sociaux à l'occupation sur le terrain: Ethnographie (très) participante de l'occupation de La Défense avec le collectif des Indignés ('Démocratie Réelle')." Multitudes, no. 50: 96-102. http://dx.doi.org/10. 3917/mult.050.0096.

Schegloff, Emanuel A., Gail Jefferson, and Harvey Sacks

1977 "The Preference for Self-Correction in the Organization of Repair in Conversation." Language 53, no. 2: 361-82. http://dx.doi.org/10.2307/ 413107.

Scott, Alan

2010 "La Nouvelle gestion publique en perspective: une confrontation AngleterreAutriche." Économies et Sociétés, no. 44: 509-34.

Sedgwick, Eve Kosofsky

2003 "Paranoid Reading and Reparative Reading, or, You're So Paranoid, You Probably Think This Essay Is About You.” In Touching Feeling: Affect, Pedagogy,

Silverstein, Michael

Performativity, 123-51. Durham, N.C.: Duke University Press.

1993 “Metapragmatic Discourse and Metapragmatic Function.” In Reflexive Language: Reported Speech and Metapragmatics, edited by John A. Lucy, 33-58. New York: Cambridge University Press. 
Soulié, Charles

2009 “Une leçon pour Valérie Pécresse: Les inégalités sociales dans l’enseignement supérieur.” In L'Université et la recherche en colère: Un mouvement social inédit, edited by Claire-Akiko Brisset, 203-18. Broissieux, France: Editions du Croquant.

2012 Un mythe à détruire? Origines et destin du Centre universitaire expérimental de Vincennes. Saint-Denis, France: Presses Universitaires de Vincennes.

Stewart, Kathleen

2007 Ordinary Affects. Durham, N.C.: Duke University Press.

Stewart, Kathleen, and Susan Harding

1999 "Bad Endings: American Apocalypsis." Annual Review of Anthropology 28: 285310. http://dx.doi.org/10.1146/annurev.anthro.28.1.285.

Tartakowsky, Danielle

2004 "La construction sociale de l'espace politique: Les usages politiques de la place de la Concorde des annees 1880 a nos jours." French Historical Studies 27, no. 1:

Thorkelson, Eli 145-73. http://dx.doi.org/10.1215/00161071-27-1-145.

2014 "Hostile Futures: Radical Philosophy and the French University Movement of 2009.” PhD dissertation, University of Chicago.

Todd, Zoe

2015 "Indigenizing the Anthropocene." In Art in the Anthropocene: Encounters among Aesthetics, Politics, Environments, and Epistemologies, edited by Heather Davis and Etienne Turpin, 241-54. London: Open Humanities Press.

van de Sande, Mathijs

2015 "Fighting with Tools: Prefiguration and Radical Politics in the Twenty-First Century.” Rethinking Marxism 27, no. 2: 177-94. http://dx.doi.org/10.1080/ 08935696.2015.1007791.

Vinokur, Annie

2008 "Vous avez dit 'autonomie'?" Mouvements, nos. 55-56: 72-81. http://dx.doi. org/10.3917/mouv.055.0072.

Vivant, Elsa

2010 “The (re)Making of Paris as a Bohemian Place?” Progress in Planning 74, no. 3: 107-52. http://dx.doi.org/10.1016/j.progress.2010.05.002.

Wright, Susan, and Jakob Williams Ørberg

2008 "Autonomy and Control: Danish University Reform in the Context of Modern Governance." Learning and Teaching: The International Journal of Higher Education in the Social Sciences 1, no. 1: 27-57. http://dx.doi.org/10.3167/ 175522708783113550 .

Yates, Luke

2015 "Rethinking Prefiguration: Alternatives, Micropolitics and Goals in Social Movements." Social Movement Studies 14, no. 1: 1-21. http://dx.doi.org/10. 1080/14742837.2013.870883.

Yusoff, Kathryn

2016 "Anthropogenesis: Origins and Endings in the Anthropocene." Theory, Culture, and Society 33, no. 2: 3-28. http://dx.doi.org/10.1177/0263276415581021. 